\title{
Organic substrates and their effects on the emergence and initial growth of Tamarindus indica seedlings
}

The reuse of organic waste and destination as alternative substrates becomes an important strategy for the production of economically viable and ecologically sustainable forest seedlings. Thus, the objective of the study was to evaluate the influence of different substrates and compositions (proportions) on the emergence and initial growth of Tamarindus indica seedlings. For this, nine different substrates were formulated: bovine manure (EB), buriti paú (PB) and carnauba residue (RC) in the proportions of $75 \%, 50 \%$ and $25 \%$ complemented with washed sand and an additional treatment only with washed sand, considered as control. T. indica seeds were sown and conducted for 50 days. The following were evaluated: emergency speed index; mean emergence time, height of the shoot, diameter of the stem, number of leaves, length of the root system, dry mass of the shoot, dry mass of the root system, total dry mass and Dickson's quality index. For the variables of emergence of tamarind seeds, treatments with bovine manure and $25 \%$ buriti paú more efficient. In the growth of the seedlings, the best results of diameter, number of leaves, production of dry mass of the root system, aerial part or total part of the seedlings, in addition to Dickson's quality index were found in the proportion of $50 \%$ of bovine manure, followed by buriti paú. These results indicate that the substrates bovine manure and paú de buriti in the proportion $50 \%$ are the most suitable for the preparation of substrate for the production of $\mathrm{T}$. indica seedlings.

Keywords: Proportions; Seedling production; Residues; Dry mass; Dickson quality index.

\section{Substratos orgânicos e seus efeitos na emergência e crescimento inicial de mudas de Tamarindus indica}

\begin{abstract}
O reaproveitamento de resíduos orgânicos e sua destinação como substratos alternativos torna-se uma importante estratégia para a produção de mudas florestais economicamente viáveis e ecologicamente sustentáveis. Assim, o objetivo do estudo foi avaliar a influência de diferentes substratos e composições (proporções) na emergência e crescimento inicial de mudas de Tamarindus indica. Para isso, foram formulados nove diferentes substratos: esterco bovino (EB), buriti paú (PB) e resíduo de carnaúba (RC) nas proporções de $75 \%, 50 \%$ e $25 \%$ complementados com areia lavada e um tratamento complementar apenas com areia lavada , considerado como controle. As sementes de T. indica foram semeadas e conduzidas por 50 dias. Foram avaliados: índice de velocidade de emergência; tempo médio de emergência, altura da parte aérea, diâmetro do caule, número de folhas, comprimento do sistema radicular, massa seca da parte aérea, massa seca do sistema radicular, massa seca total e índice de qualidade de Dickson. Para as variáveis de emergência de sementes de tamarindo, os tratamentos com esterco bovino e $25 \%$ de buriti paú foram mais eficientes. No crescimento das mudas, os melhores resultados de diâmetro, número de folhas, produção de massa seca do sistema radicular, parte aérea ou parte total das mudas, além do índice de qualidade de Dickson foram encontrados na proporção de $50 \%$ de. esterco bovino, seguido de buriti paú. Esses resultados indicam que os substratos esterco bovino e paú de buriti na proporção de $50 \%$ são os mais adequados para o preparo do substrato para a produção de mudas de T. indica.
\end{abstract}

Palavras-chave: Proporções; Produção de mudas; Resíduos; Massa seca; Índice de qualidade de Dickson.

Topic: Ciências Florestais

Reviewed anonymously in the process of blind peer.
Received: 04/12/2020

Approved: $23 / 12 / 2020$
Genilda Canuto Amaral (iD

Universidade Federal do Espírito Santo, Brasil http://lattes.cnpq.br/0868640938003832 http://orcid.org/0000-0002-8601-7780

genildacanuto@gmail.com

Yara Karolynne Lopes Abreu

Universidade Federal do Piaui, Brasil

http://lattes.cnpq.br/6965492402142066

yaralopesa@gmail.com

Mariana Duarte Silva Fonseca (DD)

Universidade Federal do Espírito Santo, Brasil

http://lattes.cnpq.br/2484792270411571

http://orcid.org/0000-0002-3600-9125

duarte.123@hotmail.com

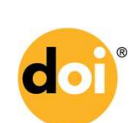

DOI: 10.6008/CBPC2179-6858.2020.007.0008

\author{
Luciana de Souza Lorenzoni Paschoa (iD \\ Universidade Federal do Espírito Santo, Brasil \\ http://lattes.cnpq.br/8762306987229946 \\ http://orcid.org/0000-0002-4333-1622 \\ lucianaloren27@gmail.com \\ Elbya Leão Gibson (iD) \\ Universidade Federal do Espírito Santo, Brasil \\ http://lattes.cnpq.br/1669134343402390 \\ http://orcid.org/0000-0003-1924-1851 \\ elbyagibson@hotmail.com \\ José Eduardo Macedo Pezzopane (iD \\ Universidade Federal do Espírito Santo, Brasil \\ http://lattes.cnpq.br/3640768649683482 \\ http://orcid.org/0000-0003-0024-4016 \\ pezzopane2007@yahoo.com.br
}

Referencing this:

AMARAL, G. C.; ABREU, Y. K. L.; FONSECA, M. D. S.; LORENZONI, L. S.; GIBSON, E. L.; PEZZOPANE, J. E. M.. Organic substrates and their effects on the emergence and initial growth of Tamarindus indica seedlings. Revista Ibero Americana de Ciências Ambientais, v.11, n.7, p.83-92, 2020. DOI: http://doi.org/10.6008/CBPC2179-

$\underline{6858.2020 .007 .0008}$ 


\section{INTRODUCTION}

The forestry business has been growing substantially and methodologies such as different forms of propagation and substrate formulations have improved the forestry sector's production chain, especially in the seedling production stage (DUTRA et al., 2015).

Factors, such as temperature, air humidity, water availability, types of substrates and substrate formulations can limit the performance of propagating material, and the growing demand for forest seedlings requires the adoption of new strategies for their production, economically viable and ecologically sustainable. Seedling production is also influenced by the choice of the substrate, once it affects the emergence and quality of the seedlings (ALEXANDRE et al., 2006; WAGNER JUNIOR et al., 2006). Thus, the success of seedling production is attributed to the use of the appropriate substrate and to the correct management in the nursery phase.

The choice of the substrate has to be done considering its cost, access and availability, composition, nutritional and structural attributes (CALDEIRA et al., 2012). The appropriate substrate must also meet the physiological requirements, size and shape of the seeds (BRASIL, 2009); and to present the appropriate chemical, physical and biological characteristics for the seedling's development (CUNHA et al., 2006).

Some forest species residues, such as Mauritia flexuosa (paú de buriti) and Copernicia prunifera (carnauba bagana) are considered as an option of substrates for forestry seedling production (AMARAL et al., 2017; SANTOS et al., 2020); however, further studies related to these types of substrate in forest species need to be done. These compounds are also used as substrate for seedling production of ornamental plants (BECKMAN-CAVALCANTE et al., 2011), fruitful (ALBANO et al., 2014) and vegetables (BRITO et al., 2017). These substrates contain organic compounds with adequate chemical and physical characteristics (SILVA JÚNIOR et al., 2014), being a good option for local nurseries to their production costs (KRATZ et al., 2013).

These substrates have the potential to be used for the production of tamarind tree (Tamarindus indica L.); this species is native from Equatorial Africa, India and Southeast Asia and was introduced in Brazil, and is used for several proposes, such as: human food, once it fruits have high nutritional value (GURJÃO, 2006); the trunk is used in the timber industry (SILVA et al., 2011); and also as an ornamental plant in landscaping and afforestation projects, due to its size and its canopy structure. This species can tolerate 5 to 6 months of drought conditions, being ideal for semi-arid regions (PEREIRA et al., 2007).

Considering the importance of the multipurpose species that support drought conditions, such as tamarind tree, is important to proceed with studies with the focus on contributing to the development of production techniques for these species. Thus, our hypotheses is that the substrate with different origins and compositions will affect the emergence and initial growth of tamarind tree. Thus, the objective was to evaluate the influence of different substrates and compositions (proportions) on the emergence and initial growth of $T$. indica seedlings. 


\section{MATERIALS AND METHODS}

T. indica seeds were obtained from 10 parental plants located in the city of Curimatá, $\mathrm{PI}\left(10^{\circ} 3^{\prime} 16^{\prime \prime} \mathrm{S}\right.$ and $44^{\circ} 16^{\prime} 17^{\prime \prime}$ W). After collection, healthy seeds were selected and subsequently subjected to the dormancy breaking process by means of mechanical scarification in the opposite region of the radicle emission, with paper sandpaper $n^{\circ} 120$. The seeds were disinfected in a hypochlorite solution sodium (2\%) for 3 minutes.

Plastic polyethylene bags with dimensions of $11 \times 22 \times 5 \mathrm{~cm}$ were filled with the substrates. Nine different substrates were formulated: bovine manure (EB), buriti paú (PB) and carnauba residue $(\mathrm{RC})$ in the proportions of $75 \%, 50 \%$ and $25 \%$ complemented with washed sand and an additional treatment only with washed sand, considered as a control. Then, sowing was carried out, distributing one seed per container at a depth of $1.5 \mathrm{~cm}$ from the surface.

The experiment was carried out in a greenhouse with a $50 \%$ reduction in light for 50 days. The greenhouse belongs to the Forest Nursery of the Silviculture Sector of the Federal University of Piauí, in Bom Jesus, $\mathrm{PI},\left(09-04^{\prime} 28^{\prime \prime} \mathrm{S}\right.$ and 4421'31" W, with an average altitude of $\left.277 \mathrm{~m}\right)$, rainfall varying from 900 to 1200 $\mathrm{mm} /$ year and an average temperature of 26.5으 (VIANA et al., 2002). The climate of the Bom Jesus region according to the Köppen classification is of the hot, semi-humid type of the Aw type. Irrigation was performed twice a day (early in the morning and late afternoon).

The emergency was counted daily up to 50 days after sowing. The emergency variables were: emergency percentage (E) (LABOURIAU et al., 1976), emergency speed index (IVE) (MAGUIRE, 1962) and mean emergency time (TME, days) (EDMOND et al., 1958). The growth variables evaluated were: aerial part height $(A P A, c m)$ measured with a millimeter ruler, stem diameter $(D C, m m)$ measured with a digital caliper and number of leaves (NC). Then, the seedlings were sectioned in aerial part and root, washed in running water and the length of the root system (CSR, $\mathrm{cm}$ ) was evaluated. The seedlings were washed, packed in paper bags and taken to dry in an oven with forced air circulation at a temperature of approximately 65 ㅇ C until reaching constant weight. With this, the dry mass of the aerial part (MSPA, g), dry mass of the root system (MSSR, g) and total dry mass (MST, g) were obtained.

The Dickson Quality Index (DQI) was assessed based on the methodology of Dickson et al. (1960), with information on the dry mass of the aerial part, roots and total dry mass, height and diameter of the seedling collection.

$$
I Q D=\frac{M S T}{\left(\frac{A P A}{D C}\right)+\left(\frac{M S P A}{M S S R}\right)}
$$

Where: IQD is Dickson's quality score; MST is the weight of total dry mass (g); BB is the height ( $\mathrm{cm})$; DC is the diameter of the collection (cm); MSPA is the dry matter weight of the aerial part (g); MSSR is the weight of the root dry matter

The study was conducted with a completely randomized design in a factorial scheme $[(3 \times 3)+1]$, corresponding to three types of substrates (EB, PB and RC), three different proportions of the substrates (75\%, 50\% and $25 \%$ ) and an additional treatment washed sand (control), with four replications, composed of five seedlings each repetition, totaling 200 seedlings.

The data of the variables were checked for normality by the Shapiro-Wilk test $(p \leq 0.05)$ and 
homoscedasticity by the Bartlett test $(p \leq 0.05)$, submitted to analysis of variance by the $F$ test $(p \leq 0.05)$ and the means compared by Tukey test ( $p \leq 0.05$ ) by software R version 3.6.1 (R CORE TEAM, 2019).

\section{RESULTS}

\section{Seed emergence variables}

The emergence of $T$. indica seeds were affected by the types and proportions of the substrates (Table $1, p \leq 0.01$ ). The emergence speed index (IVE) and mean emergency time (TME) were influenced by substrates and proportions. The contrast of the substrate combinations with the washed sand was higher than that of the washed sand control treatment. It is important to note that all seeds emerged until the end of the experiment and thus the percentage of emergence $(\mathrm{PE})$ did not differ between treatments.

The highest averages of the emergence speed index were observed in seedlings conducted on the bovine manure substrate (Fig. 1A). The results show IVE for EB 9\% higher than the buriti paú (PB), substrate with the lowest average of IVE. In general, the substrate EB in the proportion 75\% presented the highest IVE, in this condition the IVE of the seeds were $12 \%$ higher than the seeds in the proportion $25 \%$ for the same substrate. On the other hand, the substrate buriti paú (PB) presented a contrasting result, in the proportion $25 \%$ of CP the IVE was $16 \%$ higher than in the proportion $75 \%$ of this same substrate. In the substrate carnauba residue (RC) the highest IVE occurred in the proportion $50 \%$.

For the proportions factor, it is noticed that each substrate presented an LVE behavior (Fig. 1A). The highest IVEs occurred in the proportions of $75 \%$ in EB, $25 \%$ in PB and $50 \%$ in RC.

Table 1: Summary of analysis of variance of germination of tamarind tree, submitted to different substrates and proportions with washed sand.

\begin{tabular}{lll}
\hline Cause of variation & IVE & TME \\
\hline Proportion (prop) & $0.99^{\text {ns }}$ & $1.69^{n s}$ \\
Substrate (sub) & $14.04^{* *}$ & $12.34^{* *}$ \\
Prop*Sub & $14.47^{* *}$ & $10.95^{* *}$ \\
Additional (add) vs. Factorial (Fat) & $16.38^{* *}$ & $17.29^{* *}$ \\
\hline
\end{tabular}

Emergency speed index (IVE) and mean emergency time (TME). ${ }^{* *}$ : significant at $p \leq 0.05 ;$ ns: not significant at $p \leq 0.05$.

High values of the emergency speed index indicate a reduction in the mean emergency time (TME). As observed in this study, the treatments that provided the highest IVE had the lowest TME (Fig. 1B). Seeds conducted on the EB substrate started to emerge from the 7th day after sowing. On the other hand, the substrates $\mathrm{PB}$ and $\mathrm{RC}$ took at least 9 days after sowing for the seeds to emerge, indicating that the EB substrate has characteristics that favor the emergence process.

Considering the studied proportions, it is noted that, as in the IVE, the TME also showed the same trend in which the most efficient proportion was $75 \%$ for the EB substrate. There was a $19 \%$ reduction in the average germination time in EB in relation to the same proportion tested for the substrate PB (substrate with higher TME). 


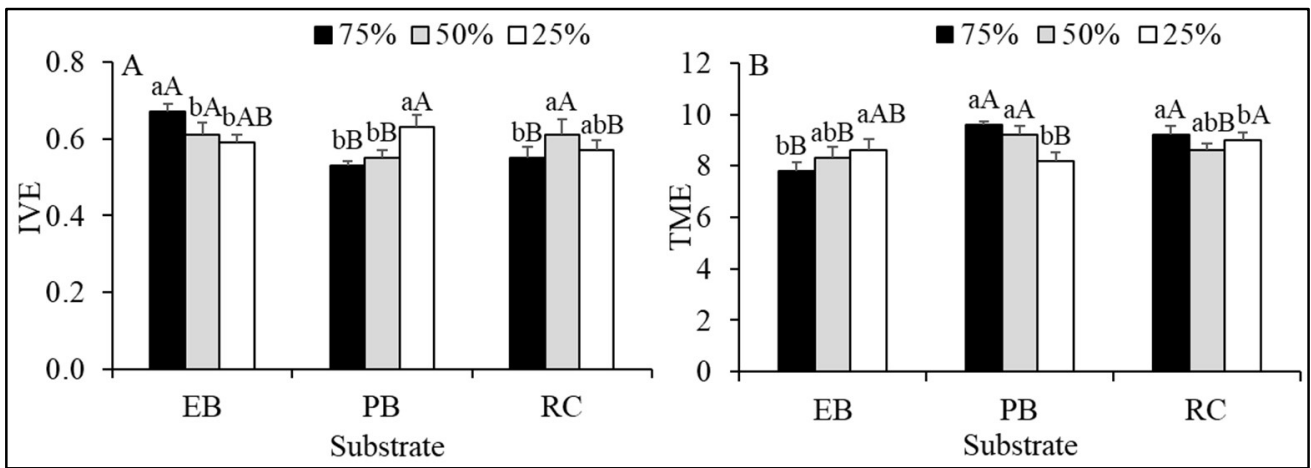

Figure 1: Index of emergency speed (IVE) and average emergency time (TME, days) of tamarind tree, submitted to

different substrates and proportions. Substrates (EB, bovine manure; PB, buriti paú; and RC, carnauba residue), proportions (75\%,50\% and 25\%). Different letters represent statistically significant differences between treatments (Tukey $p \leq 0.05)$. Lower case letters represent the difference between the substrates and upper-case letters difference between the proportions. The data are means \pm standard deviation.

\section{Growth variables}

The substrates and proportions significantly affected the growth of tamarind seedlings (Table 2). There was interaction between treatments only for the dry mass of the root system (MSSR) and for Dickson's quality index (IQD). The number of leaves (NF), total dry mass (MST), shoot height (APA), stem diameter (DC), root system length (CSR) and shoot dry mass (MSPA) did not show significant interaction between proportions and substrates, but both individually affected these variables. The contrasts of the substrate combinations with the sand were higher than those of the control treatment washed sand in all variables of (Table 2), except for the length of the root system (CSR).

Table 2: Summary of the analysis of variance of the growth variables of tamarind tree seedlings submitted to different substrates and proportions with washed sand.

\begin{tabular}{lllllllll}
\hline Cause of variation & APA $(\mathrm{cm})$ & $\mathrm{DC}(\mathrm{mm})$ & $\mathrm{NF}$ & $\mathrm{CSR}(\mathrm{cm})$ & MSPA $(\mathrm{g})$ & $\mathrm{MSSR}(\mathrm{g})$ & MST $(\mathrm{g})$ & IQD \\
\cline { 2 - 9 } Prop & $2.34^{\mathrm{ns}}$ & $0.82^{\mathrm{ns}}$ & $4.01^{*}$ & $0.75^{\mathrm{ns}}$ & $0.89^{\text {ns }}$ & $10.38^{* *}$ & $8.22^{* *}$ & $7.04^{* *}$ \\
Sub & $52.30^{* *}$ & $35.50^{* *}$ & $45.83^{* *}$ & $1.38^{\text {ns }}$ & $0.01^{\text {ns }}$ & $4.69^{* *}$ & $2.82^{\text {ns }}$ & $4.09^{*}$ \\
Prop*Sub & $0.35^{\mathrm{ns}}$ & $2.21^{\text {ns }}$ & $0.33^{\text {ns }}$ & $0.82^{\text {ns }}$ & $0.10^{\text {ns }}$ & $3.54^{* *}$ & $2.39^{\text {ns }}$ & $4.56^{* *}$ \\
Adic vs. Fat & $99.11^{* *}$ & $21.80^{* *}$ & $36.04^{* *}$ & $0.01^{\text {ns }}$ & $10.14^{* *}$ & $114.07^{* *}$ & $90.53^{* *}$ & $81.21^{* *}$
\end{tabular}

Shoot height (APA), stem diameter (DC), number of leaves (NF), length of the root system (CSR), shoot dry mass (MSPA), root dry mass (MSSR) and mass if total (MST). ** significant at $p<0.01 ;{ }^{*}$ significant at $p<0.05 ;$ n.s not significant at $p>$ 0.05. Averages followed by the same letter in the column do not differ from each other by the test (Tukey $p \leq 0.05$ ).

The growth of seedlings in general, presented the best results for the substrate bovine manure (EB) in the proportion of $50 \%$, in contrast the additional treatment (washed sand) showed the lowest results (Table 3). When analyzing the substrate with better and worse performance, it is noted that the variable height of the aerial part (APA) showed an average increase of $27 \mathrm{~cm}$ in seedlings carried out on the EB substrate, in contrast to $19.1 \mathrm{~cm}$ of RC, thus the EB seedlings obtained average growth $29 \%$ larger than RC seedlings. For the collection diameter (DC) and number of leaves (NF) the effect was similar, that is, EB stood out with results of $16 \%$ and $32 \%$ higher than the RC for the respective variables. The length of the root system (CSR), dry mass of the aerial part (MSPA) and mass if total (MST) did not differ statistically between the types of substrates. 
Table 3: Growth of tamarind seedlings submitted to different substrates and proportions with washed sand.

\begin{tabular}{|c|c|c|c|c|c|c|}
\hline \multirow{2}{*}{ Treatments } & \multicolumn{6}{|c|}{ Medium values } \\
\hline & APA $(\mathrm{cm})$ & $\mathrm{DC}(\mathrm{mm})$ & $\mathrm{NF}$ & $\operatorname{CSR}(\mathrm{cm})$ & MSPA (g) & MST (g) \\
\hline \multicolumn{7}{|c|}{ Substrate (sub) } \\
\hline EB & $27.0 a$ & $3.24 a$ & $13.2 \mathrm{a}$ & $18.50 a$ & $0.3625 a$ & $1.5219 a$ \\
\hline PB & $24.5 b$ & $3.14 a$ & $10.8 b$ & $20.95 a$ & $0.3635 a$ & $1.6220 a$ \\
\hline RC & $19.1 \mathrm{c}$ & $2.72 b$ & $9.0 c$ & $19.10 a$ & $0.3630 a$ & $1.4273 a$ \\
\hline \multicolumn{7}{|c|}{ Proportion (prop) } \\
\hline $25 \%$ & $24.0 a$ & $3.06 a$ & $11.3 \mathrm{ab}$ & $19.90 \mathrm{a}$ & $0.3683 a$ & $1.5578 a$ \\
\hline $50 \%$ & $24.0 a$ & $3.07 a$ & $11.4 a$ & $18.44 a$ & $0.3816 a$ & $1.6702 a$ \\
\hline $75 \%$ & $22.5 a$ & $2.99 a$ & $10.3 b$ & $20.20 a$ & $0.3391 a$ & $1.3431 \mathrm{~b}$ \\
\hline \multicolumn{7}{|l|}{ Contrast } \\
\hline Additional & $13.5 b$ & $2.64 \mathrm{~b}$ & $7.7 \mathrm{~b}$ & $19.90 a$ & $0.23 b$ & $0.5170 \mathrm{~b}$ \\
\hline Factorial & $23.5 a$ & $3.03 a$ & $11.0 \mathrm{a}$ & $19.51 a$ & $0.36 a$ & $1.5237 a$ \\
\hline
\end{tabular}

Shoot height (APA), stem diameter (DC), number of leaves (NF), root system length (CSR), shoot dry mass (MSPA) and total mass (MST). Averages followed by the same letter in the column do not differ from each other by the test (Tukey $p \leq 0.05)$.

The height of the aerial part (APA), diameter of the stem (DC), length of the root system (CSR) and dry mass of the aerial part (MSPA) did not present any significant difference between the proportions (Table 3). However, it is clear that the proportion of $50 \%$ shows the best results for the variables mentioned above. In addition, it can be seen that the proportion $50 \%$ stood out for the number of leaves (NF) and mass if total (MST). The equality between the proportions of $50 \%$ and $25 \%$ for MST refers in practical terms to a reduction in substrate costs.

The highest production of dry mass of the root system (MSSR) occurred in seedlings conducted in the bovine manure substrate (EB) in the proportion of $50 \%$ (Fig. $2, p \leq 0.01$ ). The substrate paú de buriti (PB) presented an average similar to EB, but with an even more important result, there was no statistical difference between the proportions evaluated, which indicates that in practical terms the proportion of $25 \%$ can be used and thus save resources. It can be seen that among the three proportions studied, $50 \%$ promoted the best MSSR results, especially for the EB substrate, since seedlings conducted in the proportion of $50 \%$ obtained MSSR $40 \%$ higher than the seedlings in the proportion of $75 \%$ of this same substrate.

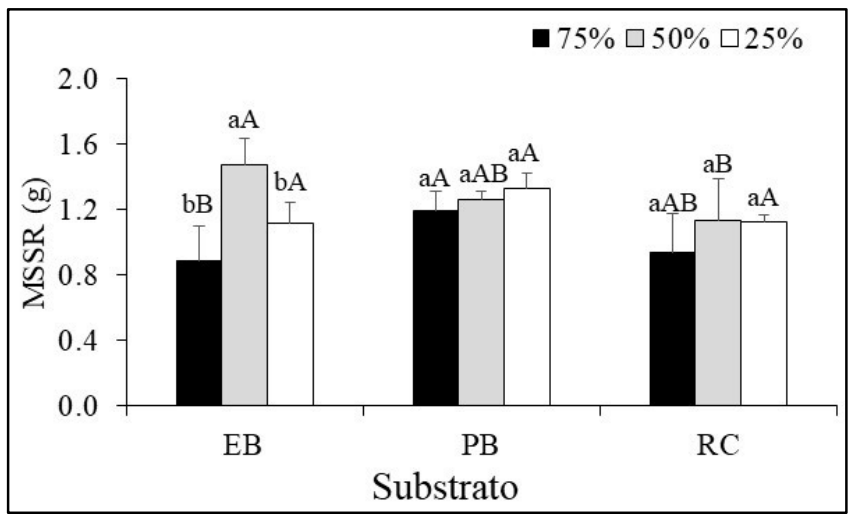

Figure 2: Dry mass of the root system (MSSR) of tamarind seedlings, submitted to different substrates (A) and proportions (B). Substrates (EB, bovine manure; PB, buriti paú; and RC, carnauba residue), proportions $(75 \%, 50 \%$ and $25 \%$ ). Different letters represent statistically significant differences between treatments (Tukey $p \leq 0.05$ ). The data are means \pm standard deviation.

The Dickson quality index (IQD) showed a higher result in the bovine manure substrate (EB) when the seedlings were conducted in a proportion of $50 \%$ (Fig. $3, p \leq 0.01$ ). However, in general terms the 
substrates paú de buriti (PB) and carnauba residue (RC) presented the highest IQD averages, 0.20 and 0.19 respectively. Note that among the proportions studied in each substrate, there was a statistical difference only for EB. In this substrate, the IQD of seedlings conducted in the proportion of $50 \%$ showed results $38 \%$ higher than seedlings conducted in the proportion of $75 \%$.

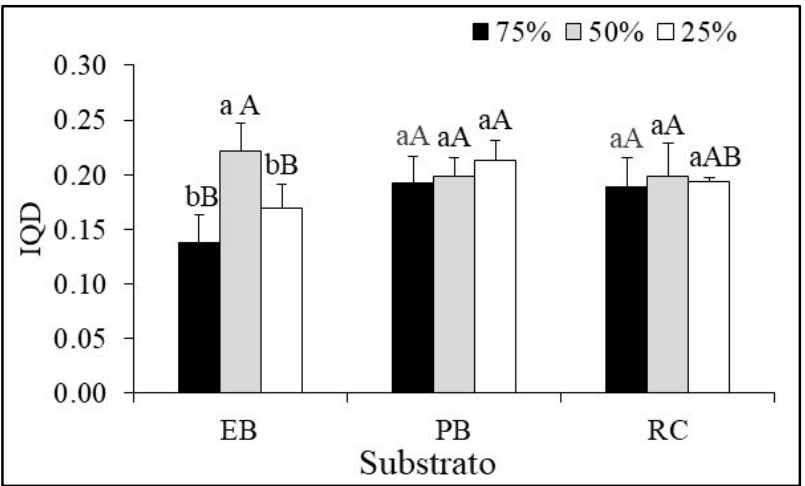

Figure 3: Dickson's quality index (IQD) of tamarind seedlings, submitted to different substrates (A) and proportions (B).

Substrates (EB, bovine manure; PB, buriti paú; and RC, carnauba residue), proportions ( $75 \%, 50 \%$ and 25\%). Different letters represent statistically significant differences between treatments (Tukey $p \leq 0.05$ ). The data are means \pm standard deviation.

\section{DISCUSSION}

Adopting organic material that would be discarded as an alternative substrate is an important outlet for reuse and for the production of economically viable and ecologically sustainable seedlings, in addition to producing quality seedlings (KRATZ et al., 2013). In previous studies, the compounds evaluated in our research were characterized by their chemical and physical characteristics (BECKMAN-CAVALCANTE et al., 2011; SILVA JÚNIOR et al., 2014; BRITO et al., 2017; ARAÚJO et al., 2018; SANTOS et al., 2020), allowing a brief knowledge about possible effects on the production process of $T$. indica seedlings.

Treatments with bovine manure and $25 \%$ of buriti paú showed efficiency for the emergence variables of tamarind seeds (Fig. 1). The organic origin of the substrates, combined with the physical characteristics of the washed sand, the greater porosity and aeration around the seeds (KOHN et al., 2016; SILVA et al., 2017) favored the emergency process. Substrates with good structure, aeration and water retention capacity, are essential in the seed emergence process and vary according to the type of compound used (POPINIGIS, 1977). The seed emergence process is considered critical in the seedling production phase, as it is the initial stage for the development of a new individual, determining characteristics that guarantee the survival of the seedlings in the field (AMARAL et al., 2017; ALEXANDRE et al., 2006).

Seeds conducted in all treatments with bovine manure and the proportion of $25 \%$ of buriti paú reduced the emergency time. This reduction in the number of days for emergencies reflects in time savings for the formation of seedlings and reduces the period necessary to remain in the nursery (COSTA et al., 2012), consequently optimizing production costs. Seeds conducted in the carnauba residue compound started to emerge from the ninth day, a result that corroborates with the literature, as the reports indicate an average 
period of 9 and 10 days for the appearance of $T$. indica seeds (SILVA et al., 2017; SOUSA et al., 2010). The reduced emergence time is a highly desired results in the seedling production process, because the longer the seedling takes to emerge from the substrate, the more susceptible it will be to environmental conditions (MARTINS et al., 1999).

In addition to the emergency, initial growth is another important phase in the forest seedling production process. Our results showed that the largest initial growth of tamarind seedlings occurred in the proportion of $50 \%$ of cattle manure, followed by the buriti paú in the same proportion. This result indicates that the $T$. indica seedlings are very responsive to compounds with bovine manure and buriti paú. The incorporation of these organic compounds physically and chemically improves the characteristics of the substrate (SILVA et al., 2012; SILVA JÚNIOR et al., 2014; BRITO et al., 2017).

Seedlings grown in the compounds with bovine manure and buriti paú showed a higher average stem diameter (DC) compared to the other treatments studied. Larger stem diameter is a desired result in the seedling production process, as a larger diameter is indicative of greater resistance to adverse conditions in the field (AZEVEDO et al., 2010). The treatments (for example, made up of bovine manure and the $50 \%$ buriti paú proportion) that resulted in greater DC also provided greater growth of the aerial part and greater number of leaves (NF) for the $T$. indica seedlings (Table 3). The physical, chemical and biological characteristics of these treatments induce a better development of the seedlings (SILVA JÚNIOR et al., 2014); mainly caused by the association between nutrient availability of these organic compounds, cation exchange capacity in the solution and improvement of water retention, porosity and aggregation of the substrate provided by the adopted treatments (SCHORN et al., 2003).

The highest production of dry matter, originating from the root system, aerial part or total part of $T$. indica seedlings, occurred in the substrates of bovine manure and buriti paú, mainly in the proportion of $50 \%$. This result reveals that these substrates in the proportion of $50 \%$ showed a good and fast response to the growth and development of the species, which, as reported by Silva Júnior et al. (2014) is associated with the fact that both organic materials have a high phosphorus content $\left(2.59 \mathrm{~g}^{\mathrm{Kg}} \mathrm{Kg}^{-1}\right)$. Phosphorus can contribute to the production of dry root mass and, therefore, total dry mass (FREITAS et al., 2006).

The higher quality of $T$ indica seedlings was also characterized by the Dickson quality index (IQD) considered a good seedling quality indicator (AZEVEDO et al., 2010). The results show the viability of bovine manure and buriti paú in a proportion of $50 \%$ in the seedling production process. We emphasize that the use of bovine manure reduces the costs of producing the substrate (DUTRA et al., 2013). In addition, it is important to note that bovine manure, when mixed with other components, improves aeration and drainage of the substrate and quickly releases large amounts of nutrients to plants (CORREIA et al., 2001).

Our results confirm the hypothesis that the organic origin and the different proportions of the substrates affect the emergence and initial growth of the tamarind tree. In the three types of organic material tested, the proportion of $50 \%$ stood out. Thus, the evaluation of organic waste such as cattle manure, buriti paú and carnauba residue must be considered in forest nurseries, especially in Piauí, as it is an economically viable and ecologically sustainable alternative for reuse. The information obtained through our study will 
help nurseries in the region to produce $T$ indica seedlings.

\section{CONCLUSIONS}

Substrates formulated with organic bovine manure obtained the best results for the emergence of $T$ indica seeds. Organic wastes from cattle manure and buriti paú provided the best growth and quality of $T$ indica seedlings. Among the tested proportions, based on the production of total dry mass, the $50 \%$ proportion of both cattle manure and buriti paú is more suitable for preparing substrate for the production of $T$ indica seedlings of quality.

\section{REFERENCES}

ALBANO, F. G.; MARQUES, A. S.; CAVALCANTE, Í. H. L.. Substrato alternativo para produção de mudas de mamoeiro formosa (cv. Caliman). Científica, Jaboticabal, v.42, n.4, p.388-395, 2014. DOI: http://dx.doi.org/10.15361/1984$\underline{5529.2014 v 42 n 4 p 388-395}$

ALEXANDRE, R. S.; WAGNER JUNIOR, A.; NEGREIROS, J. R. S.; BRUCKNER, C. H.. Estádio de maturação dos frutos e substratos na germinação de sementes e desenvolvimento inicial de plântulas de jabuticabeira. Revista Brasileira de Agrociência, v.12, n.2, p.227-230, 2006.

AMARAL, G. C.; AGUIAR JÚNIOR, A. L.; ABREU, Y. K. L.; CAVALCANTE, M. Z. B.; FERREIRA, J. C. B.; PEZZOPANE, J. E. M.. Emergência e crescimento de plântulas de Leucaena leucocephala em diferentes substratos. Revista Instituto de Floresta, v.29 n.2 p.157-167. 2017 2017. DOI. http://doi.org/10.24278/2178-5031.201729202

ARAÚJO, E. F.; ARAUCO, A. M. S.; DIAS, B. A. S.; SILVA, G. C.; NÓBREGA, R. S. A.. Substratos da Mauritia flexuosa e águas residuais da suinocultura sobre o crescimento e a qualidade de mudas de Acacia mangium. Revista Ciência Agronômica, v.49, n.2, p.298-306, 2018. DOI:

http://doi.org/10.5935/1806-6690.20180034

AZEVEDO, I. M. G.; ALENCAR, R. M.; BARBOSA, A. P.; ALMEIDA, N. O.. Estudo do crescimento e qualidade de mudas de marupá (Simarouba amara Aubl) em viveiro. Acta Amazônica, v.40, n.1, p.57-164, 2010. DOI: https://doi.org/10.1590/S0044-59672010000100020

BECKMANN-CAVALCANTE, M. Z.; AMARAL, G. C.; SILVA, A. A.; CAVALCANTE, I. H. L.; LIMA, M. P. D.. Alternative substrates for production of Heliconia psittacorum $\mathrm{L}$. seedlings under shade and open field conditions. African Journal of Biotechnology, Nairobi, v.10, n.88, p.1527215277, 2011. DOI: http://doi.org/10.5897/AJB11.1028

BRASIL. Ministério da Agricultura, Pecuária e Abastecimento. Regras para análise de sementes. Secretaria de Defesa Agropecuária. Brasília: MAPA, 2009.

BRITO, L. S. B.; BECKMANN-CAVALCANTE, M. Z.; AMARAL, G. C.; SILVA, A. A.; AVELINO, R. C.. Reutilização de resíduos regionais como substratos na produção de mudas de cultivares de alface a partir de sementes com e sem peletização. Revista de la Facultad de Agronomía, La Plata, v.116, n.1, p.51-61, 2017.
CALDEIRA, M. V. W.; DELAMELINA, W. M.; LUBE, S. G.; GOMES, D. R.; GONSALVES, E. O.; ALVES, A. F.. Biossólido na composição de substrato para a produção de mudas de Tectona grandis. Revista Floresta, v.23, n.12, p.77-84, 2012. DOI: http://dx.doi.org/10.5380/rf.v42i1.26302

CORREIA, D.; CAVALCANTI JÚNIOR, A. T.; COSTA, A. M. G.. Alternativas de substratos para a formação de portaenxertos de gravioleira (Annona muricata) em tubetes. Fortaleza: EMBRAPA Agroindústria Tropical, 2001.

COSTA, E.; FERREIRA, A. F. A.; SILVA, P. D. L.; NARDELLI, E. M. V.. Diferentes composições de substratos e ambientes protegidos na formação de mudas de pé-franco de tamarindeiro. Revista Brasileira de Fruticultura, Jaboticabal, v.34, n.4, p.1189-1198, 2012. DOI:

http://dx.doi.org/10.1590/S0100-29452012000400028

CUNHA, A. M.; CUNHA, G. M.; SARMENTO, R. A.; CUNHA, G. M.; AMARAL, J. F. T.. Efeito de diferentes substratos sobre o desenvolvimento de mudas de Acacia sp. Revista Árvore, Viçosa, v.30, n.2, p.207-214, 2006. DOI:

http://dx.doi.org/10.1590/S0100-67622006000200007

DICKSON, A. L. E. A. F. A.; HOSNER, J. F.. Quality appraisal of white spruce and white pine seedling stock in nurseries. The Forest Chronicle, West Mattawa, v.36, p.10-13, 1960. DOI: https://doi.org/10.5558/tfc36010-1

DUTRA, T. R.; GRAZZIOTTI, P. H.; SANTANA, R. C.; MASSAD, M. D.. Qualidade de mudas de copaíba produzidas em diferentes substratos e níveis de sombreamento. Floresta, Paraná, v.45, n.3, p.635-644, 2015. DOI: http://doi.org/10.5380/rf.v45i3.35686

EDMOND, J. B.; DRAPALA, W. J.. The effects of temperature, sand and soil, and acetone on germination of okra seed. Proceedings of the American Society for Horticultural Science, Alexandria, v.71, n.2, p.428-434, 1958.

FREITAS, T. A. S.; BARROSO, D. G.; CARNEIRO, J. G. A.; PENCHEL, R. M.; FIGUEIREDO, F. A. M. M.. Mudas de eucalipto produzidas a partir de miniestacas em diferentes recipientes e substratos. Revista Árvore, Viçosa, v.30, p.519528, 2006. DOI: http://dx.doi.org/10.1590/S0100$\underline{67622006000400004}$ 
GURJÃO, K. C. O.. Desenvolvimento, armazenamento e secagem de tamarindo (Tamarindus indica L.). Tese (Doutorado em Agronomia) - Universidade Federal da Paraíba, Areia, 2006.

KOHN, L. S.; CARDUCCI, C. E.; SILVA, K. D. C. R.; SANTOS BARBOSA, J.; FUCKS, J. S.; BENEVENUTE, P. A. N..

Desenvolvimento das raízes de linho (Linum usitatissimum L.) em dois anos de cultivo sobre Cambissolo Húmico.

Scientia Agraria, Curitiba, v.17, n.1, 2016. DOI: http://dx.doi.org/10.5380/rsa.v17i1.46191

KRATZ, D.; WENDLING, I.; NOGUEIRA, A. C.; SOUZA, P. V. D.. Substratos renováveis na produção de mudas de Eucalyptus benthamii. Ciência Florestal, Santa Maria, v.23, n.4, p.607621, 2013.

LABOURIAU, L. G.; VALADARES, M. B.. On the germination of seeds of Calotropis procera. Anais da Academia Brasileira de Ciências, São Paulo, v.48, p.174-186. 1976.

MAGUIRE, J. D.. Speeds of germination-aid selection and evaluation for seedling emergence and vigor. Crop Science, v.2, p.176-177, 1962. DOI: https://doi.org/10.2135/cropsci1962.0011183X0002000200 $\underline{33 x}$

MARTINS, C. C.; NAKAGAWA, J.; BOVI, M. L. A.. Efeito da posição da semente no substrato e no crescimento inicial das plântulas de Palmito-Vermelho (Euterpe espiritosantensis Fernandes - Palmae). Revista Brasileira de Sementes, Brasília, v.21, n.1, p.164-173, 1999. DOI: http://dx.doi.org/10.17801/0101-3122/rbs.v21n1p164-173

PEREIRA, P. C.; FREITAS, R. S.; MELO, B.; FRANZÃO, A. A. PEREIRA, A. P.; SANTANA, J. G.; LUZ, J. M. Q.; MARTINS, M.. A cultura do tamarindeiro (Tamarindus indica L.). Bioscience Journal, Uberlândia, v.24, n.4, p.73-79, 2007.

POPINIGIS, F.. Fisiologia da semente. Brasília: AGIPLAN, 1977.

R CORE TEAM. R: A Language and Environment for Statistical Computing. Vienna: R Foundation for Statistical Computing, 2019.

DUTRA, T. R.; DUTRA, M. M.; SARMENTO, Q.; FELIPE, M.; OLIVEIRA, J. C.. Substratos alternativos e métodos de quebra de dormência para produção de mudas de canafístula.

Revista Ceres, v.60, n.1, p.72-78, 2013. DOI: http://doi.org/10.1590/s0034-737×2013000100011

SANTOS, E. O.; ARAÚJP, A. M. D.; DIAS, B. O.; ARAÚJO, E. F.; BOECHAT, C. L.; PORTO, D. L.. Use of alternative organic compounds in the initial growth and quality of

Anadenanthera colubrina (Vell. Brenan) seedlings. Madera y Bosques, Xalapa, v.26, n.1, p.e2611753. 2020. DOI: http://doi.org/10.21829/myb.2019.2611753

SCHORN, L.; FORMENTO, S.. Produção de mudas florestais. Blumenau: FURB, 2003.

SILVA JÚNIOR, J. V.; BECKMANN-CAVALCANTE, M. Z.; BRITO, L. P. S.; AVELINO, R. C.; CAVALCANTE, Í. H. L..

Aproveitamento de materiais alternativos na produção de mudas de tomateiro sob adubação foliar. Revista Ciência Agronômica, Fortaleza, v.45, n.3, p.528-536, 2014. DOI: https://doi.org/10.1590/S1806-66902014000300013

SILVA, D. D. A.; MACHADO, C. G.; CRUZ, S. C. S.; VESPUCCI, I. L.; ARAUJO, Y. J. D.. Temperatura e substrato para o teste de germinação de sementes de tamarindo. Revista Espacios, v.38, n.14, p.4, 2017.

SILVA, G. B. P.; BARROS, G. L.; ALMEIDA, J. P. N.; PROCÓPIO, I. J. S.; MEDEIROS, P. V. Q.. Tempo de germinação e desenvolvimento inicial na produção de mudas Tamarindus Indica L. Revista Verde de Agroecologia e Desenvolvimento Sustentável, Mossoró, v.6, n.2, p.58-63, 2011.

SILVA, J. A.; OLIVEIRA, A. P.; ALVES, G. D. S.; CAVALCANTE, L. F.; OLIVEIRA, A. N.; ARAÚJO, M. A.. Rendimento do inhame adubado com esterco bovino e biofertilizante no solo e na folha. Revista Brasileira de Engenharia Agrícola e Ambiental, Campina Grande, v.16, n.3, p.253-258, 2012. DOI: https://doi.org/10.1590/S1415-43662012000300003

SOUSA, B. M. M.; BRUNO, R. L. A.; DORNELAS, C. S. M.; ALVES, E. U.; ANDRADE, A. P.; MASCIMENTO, L. C.. Caracterização morfológica de frutos e sementes e desenvolvimento pós-seminal de Tamarindus indica L. eguminosae: caesalpinioideae. Revista Árvore, Viçosa, v.34 n.6, 2010. DOI: http://doi.org/10.1590/S010067622010000600006

VIANA, T. V. A.; VASCONCELOS, D. V.; AZEVEDO, B. M.; SOUZA, B. F.. Estudo da aptidão agroclimática do estado do Piauí para o cultivo da aceroleira. Revista Ciência Agronômica, Fortaleza, v.33, n.2, p.5-12, 2002.

WAGNER JUNIOR, A.; ALEXANDRE, R. S.; NEGREIROS, J. R. S. PIMENTEL, L. D.; SILVA, J. O. C.; BRUCKNER, C. H.. Influência do substrato na germinação e desenvolvimento inicial de plantas de maracujazeiro amarelo (Passiflora edulis Sims f. fl avicarpa Deg). Ciência e Agrotecnologia, v.30, n.4, p.643647, 2006. DOI: http://doi.org/10.1590/S141370542006000400008

A CBPC - Companhia Brasileira de Produção Científica (CNPJ: 11.221.422/0001-03) detém os direitos materiais desta publicação. Os direitos referem-se à publicação do trabalho em qualquer parte do mundo, incluindo os direitos às renovações, expansões e disseminações da contribuição, bem como outros direitos subsidiários. Todos os trabalhos publicados eletronicamente poderão posteriormente ser publicados em coletâneas impressas sob coordenação da Sustenere Publishing, da Companhia Brasileira de Produção Científica e seus parceiros autorizados. Os (as) autores (as) preservam os direitos autorais, mas não têm permissão para a publicação da contribuição em outro meio, impresso ou digital, em português ou em tradução. 